\title{
Enhancement of Somatic Embryogenesis by Mature and Immature Seeds in Wheat (Triticum aestivum L.)
}

\author{
Supria Saha \\ Plant Genetic Engineering Lab., Institute of Biological Sciences, \\ University of Rajshahi, Rajshahi-6205, Bangladesh

\begin{abstract}
Zohorul Islam
Department of Genetic Engineering and Biotechnology, University of Rajshahi, Rajshahi-6205, Bangladesh
\end{abstract} \\ Sadequl Islam \\ Department of Zoology, University of Rajshahi, \\ Rajshahi-6205, Bangladesh
}

Mirza Fida Hassan

Plant Genetic Engineering Lab., Institute of Biological Sciences, University of Rajshahi, Rajshahi-6205, Bangladesh

Md. Shahadat Hossain

Department of Genetic Engineering and Biotechnology, University of Rajshahi, Rajshahi-6205, Bangladesh

S. M. Shahinul Islam (Corresponding author)

Plant Genetic Engineering Lab., Institute of Biological Sciences, University of Rajshahi, Rajshahi-6205, Bangladesh

E-mail: shahin_ibsc@ru.ac.bd 
Received: May 27, 2017 Accepted: June 28, 2017 Published: July 7, 2017

doi:10.5296/jbls.v8i2.11529

URL: https://doi.org/10.5296/jbls.v8i2.11529

\begin{abstract}
A suitable plant regeneration system has been established using 3-4 weeks old calli derived from immature and mature seeds of four wheat varieties viz. Pavon 76, Akbar, Barkat, and Kanchan. As plant growth regulators, various auxins (2,4-D, BAP and IAA) either single or in combination were used in MS medium. The variety Pavon 76 showed maximum $(72.25 \%)$ callus induction and Akbar exhibited the lowest (37.78\%) from calli derived from immature seeds. Hormonal effects on callus induction were evaluated and significant results were found in case of genotypes at $\mathrm{P}<0.01$. Out of four genotypes, the highest frequency of plant regeneration was recorded in Pavon 76 (67.00\%) and lowest in Kanchan (43.10\%) when 1.5 $\mathrm{mg} / \mathrm{l} \mathrm{BAP}$ and $0.5 \mathrm{mg} / \mathrm{l}$ IAA was added in the medium. It was observed that Pavon 76 produced highest number of green plants than others. For mature seeds all of the mentioned genotypes showed significant difference with maximum frequency of callusing in Pavon 76 (69.57\%) in $\mathrm{MS}+2.5 \mathrm{mg} / \mathrm{l}$ 2,4-D followed by Kanchan (60.84\%), Barkat (52.73\%), and Akbar (47.19\%). For plant regeneration, Pavon 76 also showed best performance $(64.36 \%)$ in $\mathrm{MS}+2.0 \mathrm{BAP}+1.0 \mathrm{mg} / \mathrm{l} \mathrm{IAA}$, using calli derived from mature seeds. The other genotypes Barkat, Kanchan and Akbar exhibited 59.44, 52.71 and 52.32\% regeneration in the same medium respectively. Here, the lowest regeneration (40.63\%) was found in Akbar. In this case, it was aimed to establish a suitable protocol for in vitro callus induction and regeneration for advance biotechnological research on wheat in Bangladesh.
\end{abstract}

Keywords: Embryogenesis, Triticum aestivum, callus, in vitro, plant growth regulators, plant regeneration.

\title{
1. Introduction
}

Biotechnological approaches have the potential tools to complement conventional methods that include many factors responsible for the frequencies of callus induction and plant regeneration in wheat and other cereal crops (Polumahanthi et al., 2014; Haque and Islam, 2014; Siddique et al., 2014; Mohammad et al., 2014; Islam, 2010). Plant growth regulators and optimization of their proper dosages are also very important for success in in vitro culture (Kouassi et al., 2017; Bhattacharjee and Islam, 2014; Morshed et al., 2014). The somatic and gametic embryogenesis on major cereal crops report that regeneration capability depends on genotype (Ksia et al., 2008; Islam et al., 2001). Some methods like mutation and haploid breeding, somaclonal variation, genetic engineering etc. also have been gaining importance for the creation of new variability (Saika and Toki, 2010; Croughan and Chu, 1991; Ho and Vasil, 1983). Among them, the genotype and nutrient composition are major sources of variation in in vitro culture (Delporte et al., 2014; Khatun et al., 2003; Khanna and Raina, 1998). Callus culture through mature and immature embryo has often been applied to solve some practical problems in wheat breeding systems. However, callus induction frequencies 
vary from genotype to genotype (Najat et al., 2014; Mahmood et al., 2009) and also vary much dependent on a proper combination and concentration of plant growth regulators are reported by Shafquat et al. (2009). Establishment of reliable tissue culture protocols for callus induction on somatic embryogenesis and its subsequent regeneration has been described in wheat (Noor et al., 2009) and for maize Morshed et al. (2016). Direct organogenesis has also been studied in wheat (Li et al., 1992) using shoot tips (Viertel and Hess, 1996); glumella and lemma (Lu et al., 1988); mature and immature wheat embryos (Sarker et al., 2007; Ozgen et al., 1996). Works on immature embryos have been reported by various researchers to be the most responsive to tissue culture conditions and showed relatively high rate of callus induction as compared to mature embryos (Shah et al., 2003). Moreover, mature embryos are readily available throughout the year and being used for advance biotechnological research (Morshed et al., 2014; Patnaik et al., 2006), thus necessitating the need for optimization of tissue culture protocols. There are some reports on growth and morphogenesis is remarkably affected by supplementing tissue culture medium with plant growth regulators including auxins and cytokinins. Various studies have investigated the factors which affect the plant regeneration in tissue culture including composition of culture medium, genotype and environmental factors (Fennel et al., 1996; Uppal et al., 1996; Mathias and Simpson, 1986). In this study, calli were used that derived from immature and matured seeds of four wheat varieties and also evaluated various culture conditions for obtaining high frequencies of somatic embryogenesis and plant regeneration in in vitro systems. The current study was carried out to develop a suitable protocol for in vitro callus induction and regeneration using mature and immature seeds of four local wheat genotypes and compared various explants and their potency on regeneration.

\section{Materials and Methods}

\subsection{Plant Materials}

Four wheat genotypes viz. Akbar, Barkat, Kanchan and Pavon 76 were sown during the growing season of November 2015 to January 2016 at the research field of Institute of Biological Sciences, University of Rajshahi, Bangladesh.

\subsection{Explants, Sterilization and Culture}

The explants were green spikes, harvested from the field grown plants that contained immature seeds (8-10 weeks old). Experiment was conducted using immature and mature seeds. Immature seeds were collected from spikes of selected wheat varieties 14 to 18 days after anthesis. At first, seeds were rinsed several times with distilled water, and then surface sterilized with $70 \%$ ethanol (v/v) for 2-3 min. Then seeds were washed 3-5 times with autoclaved distilled water in the laminar air flow cabinet.

\subsection{Immature Seeds}

The immature seeds were sterilized with $40 \%$ sodium hypochloride (v/v) +1 drop Tween 20 $+1-2$ drops savlon for 15-20 min by continuous shaking. Then seeds were thoroughly washed by autoclaved distilled water 4-5 times for complete removal of clorex and finally the seeds were ready for inoculation. 


\subsection{Mature Seeds}

Mature seeds were washed by running tap water and then surface sterilized with $70 \%$ ethanol and washed 3-4 times in distilled water. Then seeds were treated with $50 \%$ of sodium hypochlorite +1 drop Tween $20+1$ drop savlon; and rinsed 3-4 times with sterile distilled water. Finally the sterilized seeds were plated directly in semi-solid MS medium for callus induction.

\subsection{Regeneration}

After callus formation, they were rescued aseptically and transferred to regeneration medium $(\mathrm{RM})$. Then the regenerated shoots (approximately $3.0 \mathrm{~cm}$ long) were rescued carefully from the culture vessels and placed on rooting medium (RT) to develop sufficient roots. The rooted plants were cultured in pots after acclimatization and hardening.

\subsection{Statistical Analysis}

The average or mean values of callus induction and plant regeneration rate in wheat of mature and immature seeds were computed from three replicates with standard error (SE) and each experiment was repeated thrice. Analysis of variance (ANOVA) and list significant difference (LSD) was done by SPSS 20.0 software and MS Excel 2013.

\section{Results}

From immature seeds, the variety Pavon 76 showed maximum callus induction $(72.25 \%)$ in $\mathrm{MS}+2.5 \mathrm{mg} / \mathrm{L} 2,4-\mathrm{D}$; and the lowest value (65.50\%) was recorded in MS + $2.0 \mathrm{mg} / \mathrm{L}$ for the same variety (Table 1). The variety Akbar exhibited the lowest callusing (37.78\%) from immature embryo in $\mathrm{MS}+3.0 \mathrm{mg} / \mathrm{L}$. The effect of media and hormonal levels on CI, the varieties showed significant difference at $\mathrm{P}<0.01$. Three types of hormonal combinations were tested to observe regeneration efficiency of studied varieties and significant variations were found among them at $\mathrm{P}<0.01$ (Table 3). Out of four genotypes, the highest frequency of plant regeneration was recorded in Pavon 76 (67.00\%) in combination treatment MS+ 2.0 $\mathrm{mg} / \mathrm{L} \mathrm{BAP}+1.0 \mathrm{mg} / \mathrm{L} \mathrm{IAA}$ (Table 2). On the other hand, lowest performance was found in Kanchan (43.10\%) for treatment $1.5 \mathrm{mg} / \mathrm{L} \mathrm{BAP}$ and $0.5 \mathrm{mg} / \mathrm{L}$ IAA. Besides, it was observed that Pavon 76 produced plants with highest frequency in each treatment than other genotypes. For mature seeds the efficiency of four wheat genotypes to callus induction was observed by using three hormonal combinations. All the genotypes showed significant difference with maximum frequency of callusing in Pavon 76 (69.57\%) in treatment combination of MS + $2.5 \mathrm{mg} / \mathrm{L}$ 2,4-D followed by Kanchan (60.84\%), Barkat (52.73\%), and Akbar (47.19\%) in combination $\mathrm{MS}+2.5 \mathrm{mg} / \mathrm{L}$ 2,4-D (Table 1). The minimum value was recorded for Akbar (34.45\%) in combination MS + $3.0 \mathrm{mg} / \mathrm{L} \mathrm{2,4-D}$. It was observed that Pavon 76 showed highest callusing than other genotypes in all the hormonal combinations tested. Overall, the best performance with respect to callus induction was observed in Pavon 76 with $2.5 \mathrm{mg} / \mathrm{L}$ 2,4-D. On the other hand, efficient regenerations of four varieties were evaluated on MS medium with different concentrations of BAP and IAA. The results showed that Pavon 76 performed with the highest frequency (64.36\%) in $\mathrm{MS}+2.0 \mathrm{BAP}+1.0 \mathrm{mg} / \mathrm{L} \mathrm{IAA}$, when the calli were derived from mature embryos (Table 2). The other genotypes Barkat, Kanchan, and 
Akbar exhibited 59.44, 52.71 and $52.32 \%$ regeneration respectively in the same medium with desired phyto-hormones. The lowest regeneration (40.63\%) was recorded for Akbar in MS $+1.5 \mathrm{BAP}+0.5 \mathrm{mg} / \mathrm{l} \mathrm{IAA}$. From comparison between somatic embryogenesis calli derived from immature and mature seeds of four wheat varieties it is clear that for callus induction and regeneration in both cases, immature seeds showed better performance over mature seeds (Fig. 1).

Table 1. Effect of 2,4-D on callus induction from immature and mature seeds of four wheat varieties in MS

\begin{tabular}{cccccc}
\hline \multirow{2}{*}{$\begin{array}{c}\text { Explants } \\
\text { (seeds })\end{array}$} & $\begin{array}{c}\text { Concentrations } \\
\text { 2,4-D }(\mathrm{mg} / \mathrm{L})\end{array}$ & \multicolumn{4}{c}{ Variety and Callus induction $(\% \pm \mathrm{SE})$} \\
\cline { 2 - 6 } Immature & 2.0 & $65.50 \pm 0.87^{*}$ & $45.10 \pm 0.67^{* *}$ & $45.41 \pm 0.70^{* *}$ & $61.89 \pm 0.65$ \\
& 2.5 & $72.25 \pm 0.75^{* *}$ & $48.35 \pm 0.68$ & $55.95 \pm 0.86^{* *}$ & $65.76 \pm 0.70^{*}$ \\
& 3.0 & $68.79 \pm 0.81^{* *}$ & $37.78 \pm 0.89^{*}$ & $42.80 \pm 0.39$ & $52.59 \pm 0.99^{* *}$ \\
\hline \multirow{3}{*}{ Mature } & 2.0 & $58.21 \pm 0.89$ & $42.22 \pm 0.67$ & $39.20 \pm 0.83$ & $57.88 \pm 0.98^{*}$ \\
& 2.5 & $69.57 \pm 0.76^{* *}$ & $47.19 \pm 0.78$ & $52.73 \pm 0.76^{* *}$ & $60.84 \pm 0.79$ \\
& 3.0 & $64.02 \pm 0.71^{* *}$ & $34.45 \pm 0.64$ & $40.60 \pm 0.82^{* *}$ & $49.46 \pm 0.81$ \\
\hline
\end{tabular}

$2.0 \mathrm{mg} / 1$ 2,4-D considered as control. Significance of mean difference from controls: $\mathrm{p}<0.05^{*}, \mathrm{p}<0.01 * *$ according to LSD analysis.

Table 2. Overall efficiency of BAP and IAA concentrations on plant regeneration in four wheat varieties in MS medium

\begin{tabular}{ccccccc}
\hline \multirow{2}{*}{$\begin{array}{c}\text { Explants } \\
\text { (seeds })\end{array}$} & \multicolumn{2}{c}{ PGR's } & \multicolumn{4}{c}{ Variety and Plant regeneration $(\% \pm \mathrm{SE})$} \\
\cline { 2 - 7 } & $\begin{array}{c}\text { BAP } \\
(\mathrm{mg} / \mathrm{L})\end{array}$ & $\begin{array}{c}\text { IAA } \\
(\mathrm{mg} / \mathrm{L})\end{array}$ & Pavon 76 & Akbar & Barkat & Kanchan \\
\hline Immature & 1.5 & 0.5 & $56.14 \pm 0.99$ & $45.18 \pm 0.71$ & $53.05 \pm 0.83$ & $43.10 \pm 0.78$ \\
& 2.0 & 1.0 & $67.00 \pm 0.91$ & $55.22 \pm 0.93$ & $63.35 \pm 0.99$ & $58.63 \pm 0.85$ \\
& 2.5 & 1.5 & $58.27 \pm 0.88$ & $43.82 \pm 0.97$ & $54.20 \pm 0.85$ & $48.34 \pm 0.61$ \\
\hline Mature & 1.5 & 0.5 & $54.12 \pm 0.87$ & $40.63 \pm 0.88$ & $50.27 \pm 0.98$ & $41.26 \pm 0.69$ \\
& 2.0 & 1.0 & $64.36 \pm 0.83$ & $52.32 \pm 0.82$ & $59.44 \pm 0.79$ & $52.71 \pm 0.63$ \\
& 2.5 & 1.5 & $56.94 \pm 0.78$ & $41.75 \pm 0.72$ & $48.71 \pm 0.82$ & $46.10 \pm 0.75$ \\
\hline
\end{tabular}

Values are average of three replicates (percentage); $\mathrm{SE}=\mathrm{Standard}$ error; $\mathrm{BAP}=6$-benzylaminopurine; IAA= Indole-3-acetic acid. 
Table 3. ANOVA on the effect of variety, callus induction and plant regeneration rate of transplantation in wheat

\begin{tabular}{ccccc}
\hline Source of data & Source of variation & df & $\begin{array}{c}\text { Mean sum of square of } \\
\text { immature seed }\end{array}$ & $\begin{array}{c}\text { Mean sum of square of } \\
\text { mature seed }\end{array}$ \\
\hline Callus induction & Variety & 5 & $164.4844^{* *}$ & $182.5777^{* *}$ \\
& 2,4-D level & 2 & $4685.453^{* *}$ & $5200.853^{*}$ \\
& Error & 36 & 45.83483 & 50.87666 \\
\hline Regeneration & Variety & 5 & $148.036^{* *}$ & $164.32^{* *}$ \\
& BAP + IAA level & 2 & $4216.908^{*}$ & $4680.768^{* *}$ \\
& Error & 36 & 41.25135 & 45.789 \\
\hline
\end{tabular}

$\mathrm{df}=$ Degrees of freedom, Significance: $\mathrm{p}<0.05^{*}, \mathrm{p}<0.01 * *$

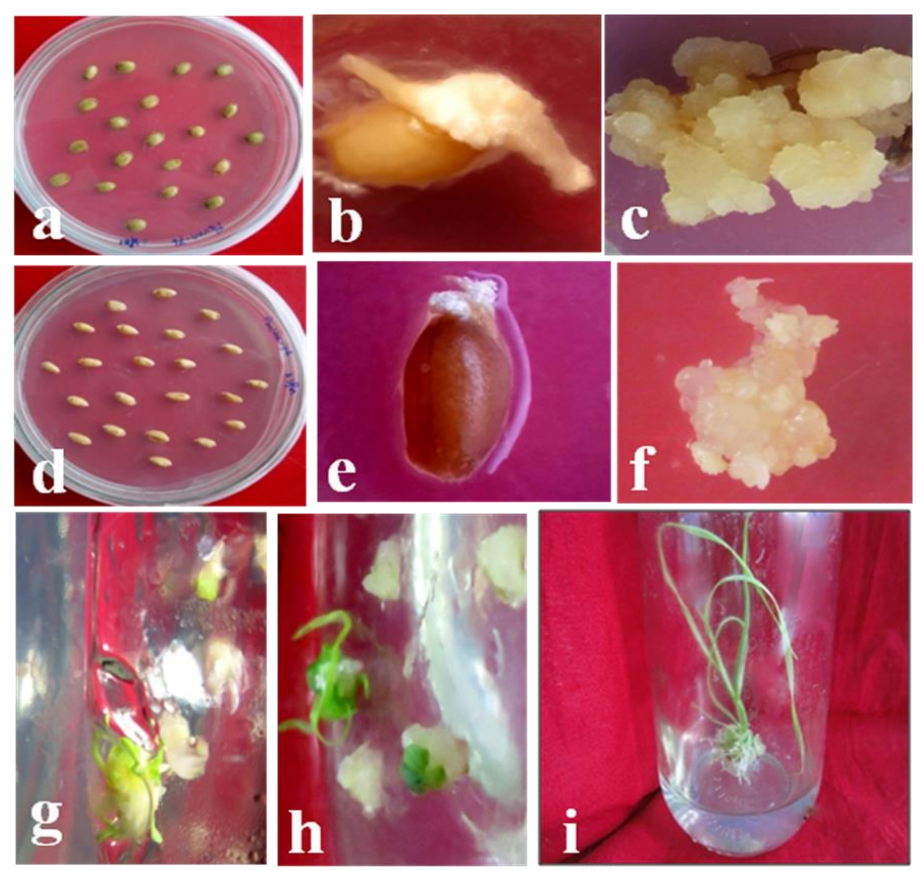

Fig. 1. Somatic embryogenesis through immature and mature seeds of wheat. a) immature seeds, b) calli initiated after 7 days of inoculation, c) 3-4 week's old calli, d) mature seeds, e) calli after 7 days of inoculation, f) calli derived from mature seeds, g) calli initiated greenish and regeneration, h) regenerated green plantlets, i) green plants with root and shoot.

\section{Discussion}

In this case immature and mature seeds derived calli were evaluated on regeneration efficiency in wheat. Significant effect on genotype and media including hormonal levels were found to callus induction (Table 3). The range of CI was 37.78-72.25\% (immature seed) and 34.45-69.57 (mature seed) in MS medium supplemented with three concentration of 2,4-D. In both cases, Pavon 76 showed maximum callusing. Kahriz et al. (2017) reported that in in vitro 
SE using plumule and radicle explants of two wheat cultivars Cakmak and Kunduru on MS induction medium amended with varying concentrations of 2,4-D. Both plumule and radicle explants were regenerative and induced variable number of somatic embryos per explants. Another study carried out by Kowalska and Arseniu (2016) to improve callus induction and plant regeneration from mature embryos of five winter wheat cultivars with various resistance levels to $P$. nodorum. For that purpose they used three type of auxins e.g. 2,4-D; 3,6-dichloro-2-methoxybenzoic acid (Dicamba); NAA, and the effect of maltose vs. sucrose were also evaluated. The results demonstrated relatively high embryogenic potential of all winter wheat cultivars they studied. Islam (2010) studied on embryoids age, size and shape for improvement of regeneration efficiency from microspore-derived embryos in wheat and reported significant effect of media and phytohormones on callus induction and regeneration that derived from anthers in wheat. The effect of different concentrations of 2,4-D for successful callus induction was reported by Munazir et al. (2010). They found that $4.0 \mathrm{mg} / \mathrm{l}$ 2,4-D was optimum to induce efficient callus induction for the wheat varieties of GA-02 $(82.60 \%)$ and Sahar (71\%). However, in some cases the frequencies of callus induction were lesser than previous reports, and it could have occurred due to different varieties of wheat. He et al. (1999) and Ganeshan et al. (2003) have documented the effect of genotypes and age of embryos on callusing. However, high (> $5 \mathrm{mg} / \mathrm{L})$ and low $(<3 \mathrm{mg} / \mathrm{L})$ concentrations of 2,4-D, reduced callus induction frequency and subsequent growth of calli reported by Munazir et al. (2010). No callus formation occurred at lower concentrations $(<2.5 \mathrm{mg} / \mathrm{l})$ of 2, 4-D in mature wheat embryos (Yasmin et al., 2001). So it could be mentioned that a suitable concentration of 2,4-D is necessary to efficiently induce callus and subsequent proliferation in tissue culture. Several authors reported optimization of 2,4-D concentrations from $2.0 \mathrm{mg} / \mathrm{L}$ to $6.0 \mathrm{mg} / \mathrm{L}$ for different wheat varieties, source of explants and culture conditions (Farooq et al., 2004; Rahman et al., 2008). Alizadeh et al. (2004) reported that gradual increase in concentration of 2,4-D, frequency of direct shoot regeneration decreased and the tendency for callus induction increased gradually. However, it was observed that higher or lower concentrations $(>2.5$ $\mathrm{mg} / \mathrm{L}$ ) of 2,4-D produced lower values of callusing than their maximum performance for all studied varieties. In this research, it has been observed that in response to plant regeneration the calli derived from immature seeds, showed significant variability on plant regeneration. The range of regenerations was recorded as (43.10-67.00\%) for immature seeds and (40.63-64.36\%) for mature seeds which expressed the wide range variations among the varieties. In this case maximum performances of plant regeneration were recorded in MS supplemented with $1.0 \mathrm{mg} / \mathrm{L} \mathrm{IAA}+2.0 \mathrm{mg} / \mathrm{L} \mathrm{BAP}$. This highest frequency (67.00 and 64.36) of plant regeneration was recorded in Pavon 76 in case of immature and mature seeds. Hence, MS supplemented with $2.0 \mathrm{mg} / \mathrm{L} \mathrm{BAP}+1.0 \mathrm{mg} / \mathrm{L}$ IAA is regarded as optimal medium for regeneration. Pathi et al. (2013) reported $35-90 \%$ plant regeneration by using immature seeds in MS with growth regulators. A maximum 6.36\% regeneration using $\mathrm{MS}+1.0 \mathrm{mg} / \mathrm{L} \mathrm{BAP}$, and $3.65 \%$ in $(\mathrm{MS}+0)$ was recorded i.e. without any PGRs (Rahman et al., 2008). In this study the values were higher than the previous reports. It may occur due to positive effect of optimal concentrations and combinations of PGR's along with the different genotypes. 


\section{Conclusion}

Food security is the burning issue in the world and also in Bangladesh. Hence, it is necessary to improve food crops as well as wheat cultivars with the application of biotechnological approaches. In most cases, wheat varieties are generally recalcitrant to in vitro tissue culture. Hence, the present study could be exploited as a standard protocol for efficient callus induction and its subsequent regeneration. Out of four varieties, Pavon 76 showed the best callusing, and the medium MS + $2.5 \mathrm{mg} / \mathrm{L} 2,4-\mathrm{D}$ influenced callus induction more effectively than other concentrations. On the other hand, for plant regeneration MS + $1.0 \mathrm{mg} / \mathrm{L} \mathrm{IAA} \mathrm{+}$ $2.0 \mathrm{mg} / \mathrm{L}$ BAP showed better performance especially for Pavon $76(67.00 \%$ and $64.36 \%)$ from immature and mature seeds respectively. The developed system might be helpful to in vitro culture of wheat and related advance research on biotechnology.

\section{Acknowledgements}

Authors are thankful to Plant Genetic Engineering Lab., Institute of Biological Sciences, and University of Rajshahi, Bangladesh for providing research and related other facilities. Financial support provided by the MOST Special allocation 2013 and scholarship provided by the NST to SS are gratefully acknowledged.

\section{References}

Alizadeh, H., Naghave, M. R., Omidi, M., \& Saatian, B. (2004). Effect of plant growth regulators on direct shoot regeneration of wheat (Triticum aestivum $\mathrm{L}$.). New direction for a diverse planet: Proceeding: 4th Int. Crop Congress Brisbane, 26 September - 1 October, Australia. https://doi.org/10.5897/AJB10.770

Bhattacharjee, B., \& Islam S. M. S. (2014). Effect of plant growth regulators on multiple shoot induction in Vanda tessellata (Roxb.) Hook. Ex G. Don an endangered medicinal orchid. International Journal of Science and Nature, 5(4), 707-712.

https://scholar.google.com/citations?view_op=view_citation\&hl=en\&user=hqwumUkAAAA J\&citation_for_view=hqwumUkAAAAJ:JV2RwH3_ST0C

Croughan, T. P., \& Chu, Q. R. (1991). Establishment of callus culture and the regeneration of plants. In: Bajaj YPS (eds) Biotechnology in Agriculture and Forestry, Springer-Verlag, Berlin, 14, 19-33.

Delporte, F., Pretova, A., du Jardin, P., \& Watillon, B. (2014). Morpho-histology and genotype dependence of in vitro morphogenesis in mature embryo cultures of wheat. Protoplasma, 251, 1455-1470. https://doi.org/10.1007/s00709-014-0647-7

Farooq, M., Rashid, H., Ihsanullah., Chaudhary, Z., \& Marwat, K. B. (2004). Comparative tissue culture response of wheat cultivars and evaluation of regenerated plants. Pakistan Journal of Biological Sciences, (7), 406-408.

https://www.researchgate.net/publication/301765463

Fennel, S., Bohorova, N., Ginkel, M., Crossa, J., \& Hoisington, D. A. (1996). Plant regeneration from immature embryos of 48 elite CIMMYT bread wheats. Theoretical and 
Applied Genetics, (41), 442-450. https://link.springer.com/article/10.1007\%2FBF00223371

Ganeshan, S., Baga, M., Harwey, B. L., Rossnagel, B. G., Scoles, G. J., \& Chibbar, R. N. (2003). Production of multiple shoots from thiadiazuron-treated mature embryos and leaf-base apical meristems of barley (Hordeum vulgare L.). Plant Cell, Tissue and Organ Culture, (73), 57-64. https://doi.org/10.1023/A:1022631807797

Haque, M., \& Islam, S. M. S. (2014). Application of cold pre-treatment and optimization of media for enhancement of anther culture response in two barley (Hordeum vulgare L.) genotypes derived from Bangladesh. Asia Pacific Journal of Molecular Biology and Biotechnology, (1), 127-136. http://www.msmbb.org.my/apjmbb/html221/221b.pdf

He, G. Y., Rooke, L., Steele, S., Bekes, F., Gras, P., Tatham, A. S., Fido, R., Barcelo, P., Shewry, P. R., \& Lazzeri, P. A. (1999). Transformation of pasta wheat (Triticum durum L. var. durum) with high molecular weight glutenin subunit genes and modification of dough functionality. Molecular Breeding, (5), 377-396.

https://link.springer.com/article/10.1023/A:1009681321708

Ho, W. J., \& Vasil, I. K. (1983). Somatic embryogenesis in sugarcane (Saccharum officinarum L.) I. The morphology and physiology of callus formation and the ontogeny of somatic embryos. Protoplasma, 118 (3), 169-180.

https://link.springer.com/article/10.1007/BF01281800

Islam, S. M. S., Bari, M. A., Amin, M. N., \& Schmid, J. E. (2001). In vitro plant regeneration through anther culture of eight wheat varieties. Plant Tissue Culture and Biotechnology, 11 (1), 31-39.

https://scholar.google.com/scholar?cluster=7460383552617014727\&hl=en\&oi=scholarr

Islam, S. M. S. (2010). Effect of embryoids age, size and shape for improvement of regeneration efficiency from microspore-derived embryos in wheat (Triticum aestivum L.). Plant Omics Journal, 3(5), 149-153. http://www.pomics.com/islam_3_5_2010_149_153.pdf

Kahriz P. P., \& Mahsa P. K. (2017) Somatic embryogenesis on plumule and radicle explants obtained from warm water hydroprimed wheat (Triticum aestivum L.) cv. Kunduru and cv. Cakmak Seeds. Sains Malaysiana, 46(1), 35-41. http://dx.doi.org/10.17576/jsm-2017-4601-05

Khanna, H. K., \& Raina, S. K. (1998). Genotype $\times$ culture media interaction response of three indica rice cultivars. Plant Cell, Tissue and Organ Culture, (52), 145-153. https://link.springer.com/article/10.1023/A:1006032303195

Khatun, M., Ali, M. H., \& Desamero, N. V. (2003). Effect of genotype and culture media on callus induction and plant regeneration from mature seed scutellum culture in rice. Plant Tissue Culture, 13, 99-107.

https://www.researchgate.net/publication/230642895_Effect_of_Genotype_and_Culture_Med ia_on_Callus_Induction_and_Plant_Regeneration_from_Matured_Rice_Grain_Culture

Ksia, E., Harzallah-Skhiri, F., Verdeil, J.L., Gouta, H., Alemanno, L., \& Bouzid, S. (2008). Somatic embryo production from immature seeds of carob (Ceratonia siliqua L.), 
histological evidence. Journal of Horticulture Science and Biotechnology, 83, 401-406.

Kouassi, M. K., Kahia, J., Kouame, C. N. Tahi, M. G., \& Koffi, E. K. (2017). Comparing the Effect of Plant Growth Regulators on Callus and Somatic Embryogenesis Induction in Four Elite Theobroma cacao L. Genotypes. Horticulture Science, 52, 142-145. https://doi.org/10.21273/HORTSCI11092-16

Kowalska, L., \& Arseniu, E. (2016). The effect of medium composition on callus induction and plant regeneration frequencies from mature embryos of wheat cultivars with various resistance to Parastagonospora nodorum. Indian research journal of genetic and biotechnology, 8(3), 183-189. www.ihar.edu.pl/download.php?id=2879

Li, Z., Xia, G. M., \& Chen, H. M. (1992). Somatic embryogenesis and plant regeneration from protoplast isolated from embryogenic cell suspension of wheat (Triticum aestivum L.). Plant Cell, Tissue and Organ Culture, (28), 79-85.

https://link.springer.com/article/10.1007/BF00039918

Lu, W. Z., She, J. M., Zhou, H. Y., \& Ge., M. R. (1988). Tissue culture of young spike, stem and node of wheat and plantlet regeneration. Jiangsu Journal of Agricultural Sciences, China, 4(1), 14-18.

Mahmood, H., Zaheer, A., Muhammad, M., Saad, I. M., Khurram, S. (2009). Effect of sorbitol in callus induction and plant regeneration in wheat. African Journal of Biotechnology, (8), 6529-6535. https://www.ajol.info/index.php/ajb/article/download/66179/53895

Mathias, R. J., \& Simpson, E. S. (1986). The interaction of genotype and culture medium on the tissue culture responses of wheat (Triticum aestivum L. em. Thell) callus. Plant Cell, Tissue and Organ Culture, (7), 1-37. http://doi.org/10.1007/BF00043918

Mohammad, A., Alam, P., Ahmad, M. M., Ali, A., \& Ahmad, J. (2014). Impact of plant growth regulators (PGRs) on callogenesis and artemisinin content in Artemisia annua L. plants. Indian Journal of Biotechnology, (13), 26-33. http://nopr.niscair.res.in/bitstream/123456789/28710/1/IJBT\%2013\%281\%29\%2026-33.pdf

Morshed, M., Siddique, A. B., \& Islam, S. M. S. (2014). Efficient plant regeneration using mature and immature embryos of maize (Zea mays L.). International Journal of Agriculture Innovations and Research, 3(3), 2319-1473.

http://www.academia.edu/10836714/Efficient_Plant_Regeneration_using_Mature_and_Imma ture_Embryos_of_Maize_Zea_mays_L._

Morshed, S., Siddique, A. B., \& Islam, S. M. S. (2016). Improvement of embryogenesis and regeneration by air desiccation in maize (Zea mays L.). Pakistan Journal of Botany, 48(3), 1139-1144.

http://en.nankai.findplus.cn/n_index_findplus_en.php?h=articles\&db=edselc\&an=edselc.2-52 $.0-84973641987$

Munazir, M., Qureshi, R., Ali, G. M., Rashid, U., Noor, S., Mehmood, K., Ali, S., \& Arshad, M. (2010). Primary callus induction, somatic embryogenesis and regeneration studies in 
selected elite wheat varieties from Pakistan. Pakistan Journal of Botany, (42), 3957-3965. http://www.pakbs.org/pjbot/PDFs/42(6)/PJB42(6)3957.pdf

Najat, H., Sripada, M. U., Fatima, G., Abdelwahd, R., Mohamed, I., \& Driss, I. (2014). Effect of genotypes and culture media on embryogenic callus induction and plantlet regeneration from mature embryos of durum wheat. Romanian Agriculture Research, (31), 50-58.

Noor, S., Ali, G. M., Rashid, U., Arshad, M., Ali, S. \& Zafar, Y. (2009). Optimization of callus induction and regeneration system for Pakistani wheat cultivars Kohsar and Khyber-87. African Journal of Biotechnology, (8), 5554-5558.

http://www.scirp.org/(S(351jmbntvnsjt1 aadkposzje))/reference/ReferencesPapers.aspx?Refer enceID=1943663

Ozgen, M., Turet, M., Ozcan, S., \& Sancak, C. (1996). Callus induction and plant regeneration from immature and mature embryos of winter wheat genotypes. Plant Breeding, (115), 455-458. http://www.pakbs.org/pjbot/PDFs/38(3)/PJB38(3)637.pdf

Pathi, K. M., Tula, S., Huda, K. M. K., Srivastava, V. K., \& Tuteja, N. (2013). An efficient and rapid regeneration via multiple shoot induction from mature seed derived embryogenic and organogenic callus of Indian maize (Zea mays L.). Plant Signaling and Behavior, 8(10), 1-6. doi: $10.4161 / \mathrm{psb} .25891$

Patnaik, D., Vishnudasan, D., \& Khurana, P. (2006) Agrobacterium-mediated transformation of mature embryos of Triticum aestivum and Triticum durum, Current Science, (91), 307-317. http://www.iisc.ernet.in/currsci/aug102006/307.pdf

Polumahanthi, S., Mani, N. S., \& Kumar, P. K. R. (2014). Callus induction and multiple shoot regeneration of Sorghum cultivars using shoot tip as an explant. International Journal of Advanced Life Sciences, 7(1), 66-73.

http://www.unitedlifejournals.com/ijals/view-article.php?id=162

Rahman, M. M., Shamsuddin, A. K. M., \& Asad, U. (2008). In vitro regeneration from mature embryos in spring wheat. International Journal of Sustainable Crop Production, (3), 76-80. http://ggfjournals.com/assets/uploads/76-80.pdf

Saika, H., \& Toki, S. (2010). Mature seed-derived callus of the model indica rice variety Kasalath is highly competent in Agrobacterium-mediated transformation. Plant Cell Reports 29(12), 1351-1364. doi: 10.1007/s00299-010-0921-x

Sarker, K. K., Kabir, A. H., Sharmin, S. A., Nasrin, Z., \& Alam, M. F. (2007). Improved somatic embryogenesis using L-asparagine in wheat (Triticum aestivum L.). Sjemenarstvo, (24), 3-4. hrcak.srce.hr/file/35298

Shafquat, Y., Imtiaz, A. K., Abdullah, K., Nighat, S., Ghulam, S. N., \& Mohammad, A. A. (2009). In vitro plant regeneration in bread wheat (Triticum aestivum L.). Pakistan Journal of Botany, (41), 869-2876.

Shah, M. I., Jabeen, M., \& Ilahi, I. (2003). In vitro callus induction, its proliferation and regeneration in seed explants of wheat (Triticum aestivum L.) var. Lu-26S. Pakistan Journal 


\section{Macrothink \\ Journal of Biology and Life Science \\ ISSN 2157-6076 2017, Vol. 8, No. 2}

of Botany, (35), 209-217. https://doi.org/10.4236/ajps.2016.717219

Siddique, A. B., Ara, I., Islam, S. M. S., \& Tuteja, N. (2014) Effect of air desiccation and salt stress factors on in vitro regeneration of rice (Oryza sativa L.), Plant Signaling and Behavior, (9), 12 (e977209- 1-10). doi: 10.4161/15592324.2014.977209

Uppal, S., Behl, R. K., Mixwagner, G., \& Elbassam, N. (1996). Callus induction and plant regeneration from embryos in bread wheat (Triticum aestivum L.). Landbauforschung Volkenrode, (46), 157-165. https://www.researchgate.net/publication/287512591

Viertel, K., \& Hess, D. (1996). Shoot tips of wheat as an alternative source for regenerable embryogenic callus cultures. Plant Cell, Tissue and Organ Culture, (44), 183-188. doi:10.1007/BF00048522

Yasmin, R., Javed, F., \& Arfan, M. (2001). Somatic embryogenesis in callus culture of wheat (Triticum aestivum L.) Accession 235/2. International Journal of Agriculture and Biology, (3), 163-166. http://www.fspublishers.org/published_papers/77992_pdf

\section{Copyright Disclaimer}

Copyright for this article is retained by the author(s), with first publication rights granted to the journal.

This is an open-access article distributed under the terms and conditions of the Creative Commons Attribution license (http://creativecommons.org/licenses/by/3.0/). 